\title{
NOMENCLATURE OF VIRUSES
}

$\mathrm{T}$ THERE has been much discussion as to the wisdom of applying to viruses binomial names of the Linnæan type, and in particular as to the advisability of doing this over the whole field and forthwith. At the Fifth International Congress of Microbiology held in Rio de Janeiro in 1950, the International Nomenclature Committee, on the advice of its virus subcommittee, held that an attempt to apply binomials to viruses in a comprehensive way is premature; it suggested what criteria could be used in any attempted classsification; further, study groups were set up for certain better-known virus groups with the view of determining whether binomials could profitably be applied to such viruses, as a beginning. Study groups were thus set up for the psittacosis-lymphogranuloma group (Chlamydozoaceae), the pox viruses, insectpathogenic viruses, the viruses related to influenza and those of the arthropod-borne encephalitides.

At $a_{0}$ symposium held in New York in January 1952 , this piecemeal 'Rio approach' was generally favoured; and two more study groups were set up for viruses related to poliomyelitis and herpes simplex respectively.

At the Sixth International Congress of Microbiology held in Rome in September 1953, the virus subcommittee of the International Nomenclature Committee considered the whole question, having before it the reports of its study groups. Nine animal virologists and six plant virologists were present at one or both of the meetings held. They decided to reiterate the conclusions of the meeting in 1950 that at present "the use of systems of classification for and the application of binomials to viruses as a whole are undesirable and should be discouraged". They also recommended that the starting date for valid Linnæan nomenclature for viruses should not yet be determined, and that until this was done names for viruses already proposed should have no standing in bacteriological nomenclature.

The subcommittee favoured, with one dissentient, the application of internationally accepted names to all viruses. On the other hand, the plant and animal virologists present, polled separately, voted by majorities against the application of Linnæan binomials to viruses at the present time. The feeling of the majority was that such names necessarily carried implications as to taxonomic relationships, and that sufficient evidence as to such relationships was not yet available.

The animal virologists, at a separate meeting, felt that the use of comprehensive systems of nomenclature such as had been introduced in teaching as well as in the literature ${ }^{1}$ would not be discontinued unless something else were offered as a substitute. Use of a Linnæan system at the moment would be particularly unfortunate if it led to an undesirable separation of practice between the animal and plant subsections. Other names were therefore put forward of such a nature that their special character was obvious, yet they could later be transferred to the Linnæan system under the International Code. Grouping of viruses should at present start at the generic level (or equivalent).

It was agreed that the report of the Chlamydozoaceae study group should be accepted; this held that the viruses related to psittacosis were closely related to the rickettsiæ and should be considered together with them. This implied their inclusion in Rickettsiales under the bacteriological code and their removal from the sphere of consideration of the virus subcommittee.

A majority vote favoured a uniform system of forming the equivalent of generic names, and rather than forming these from personal names (eponyms), favoured the use of the suffix '-virus' as shown in the appended list. Such a suffix would mark these names as being something apart from the Linnæan system but need not involve change in names if the Linnæan system were later applied to viruses. Names with the '-virus' suffix should be of the neuter gender. Though the names of viruses would be binomials, the terms 'genus' and 'species' would be avoided at present, the terms 'group' and 'group-member' or similar designation being used instead. Such names should, however, be printed in italies in scientific papers, as with Linnæan names, and capital letters would be used for group names. The names would not, however, be ascribed to authors, as under the Linnæan system, and the law of priority would not be applied at the present time. In order, therefore, to avoid confusion, the names under this system should be officially sanctioned by the International Nomenclature Committee or its virus subcommittee. The equivalent of type species should not be designated, but type strains should be déposited with appropriate collections of type cultures. Names in the appended list would be the first to receive such official sanction. The list of approved names of group members should be added to and revised from time to time. Publication of lists of newly approved names should be in the International Bulletin of Bacteriological Nomenclature and Taxonomy; but full descriptions of viruses the names of which were approved should be published in other appropriate scientific journals by specialists concerned, with the approval of the virus subcommittee.

The plant virologists, rejoining the discussions, concurred with the principles just outlined, though not committing themselves to the use of the '-virus' suffix or any particular form of 'group' name in their field. Dr. L. M. Black, chairman of the plant virus subsection of the virus subcommittee, was unable to be present; he had not been able to present a report likely to command any general acceptance among plant virologists. Dr. J. Craigie, for the bacteriophage subsection, had submitted a unanimous report which maintained that Linnæan binomials could not at present be suitably applied in the phage field. Of the animal virus study groups, that con. sidering arthropod-borne encephalitides felt that relationships within the group were at present so uncertain that application of binomial nomenclature was premature. Names were agreed to for viruses of the pox, influenza, insect-pathogenic, poliomyelitis and herpes subgroups, based on reports of the various study groups and, in some instances, modified by the main virus subcommittee.

It appeared that plant virologists were much more evenly divided concerning the use of Linnæan binomials than were animal virologists. The use of the '-virus' suffix is proposed now only for animal 


\section{No. 4405 April 3, 1954}

viruses. The subcommittee was strongly against any course of action which would prejudice future chances of a common policy for the nomenclature of all viruses, especially now that some viruses have been shown to multiply both in plants and insects. It thought that its recommendation embodied useful positive proposals for animal viruses, and yet did not compromise future parallel action with plant virologists.

A report embodying these conclusions was presented to the main International Nomenclature Committee, which approved its publication in the International Bulletin of Bacteriological Nomenclature and Taxonomy. This explanatory note is written in the belief that as wide publicity as possible for the recommendations is desirable.

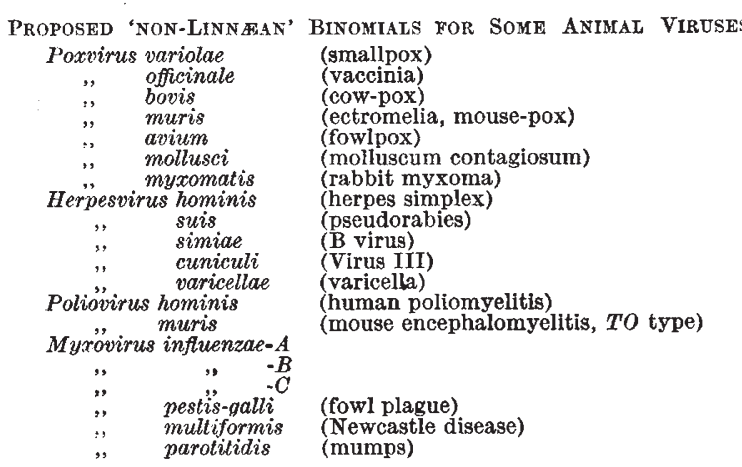

The group name Myxovirus for viruses related to influenza was intended to indicate that the viruses in question have a particular kind of affinity for certain mucins.

INSECT-PATHOGRNIC VIRUSES

Polyhedrovirus (= Borrelina): group members are $P$. bombycis, efficiens, reprimens, olethrium, campeoles, peremptor, fumiferanae.

Capsulavirus ( $=$ Bergoldia): group members are C. calyptum,

aboium, latheticum, thompsonium, clistor

Globovirus ( = Smithia) rotundum.

All the names of group members among insect pathogenic viruses correspond to the specific names listed by Bergold $^{2}$ and Steinhaus ${ }^{3}$.

\section{H. ANDREWES}

(Chairman of the Virus Subcommittee International Nomenclature Committee.)

\footnotetext{
Holmes, F. O., in "Bergey's Manual of Determinative Bacteriology",
6th edit. (Williams and Wilkins, Baltimore, 1948).

${ }^{2}$ Bergold, G. H., Ann. N.Y. Acad. Sei., 56, 995 (1953).

'Steinhaus, E. A., Ann. N.Y. Acad. Sci., 56, 517 (1953)
}

\section{RADIATION HAZARDS OF ATOMIC ENERGY*}

\begin{abstract}
A POWER programme on which a nation's economy rests inevitably has its hazards. Coal-mining is a dangerous occupation; drilling for oil and refining is subject to fire risk. Releasing energy from the atomic nucleus has its own particular dangers, notably from ionizing radiation, and the atomic-energy industry of the future will have to be planned to avoid these hazards. The cost of

* Summary of a lecture by Dr. J. F. Loutit, being the fourth of the series of public lectures arranged by the Atomic Scientists" Association end the pures ar and March 27, p. 573)
\end{abstract}

safety devices will be great, and it will be the business of statesmen to decide how to balance the economic price of safety against the hazards to health.

Experience with ionizing radiations began more than fifty years ago with the discovery of X-rays and radioactivity. Many of the early investigators fell victim to burns, diseases of the blood and bloodforming organs, and cancer. In 1921 the X-ray and Radium Protection Committee was formed in Great Britain which set national standards of safety. This task has now been taken over by the International Committee on Radiological Protection.

Originally the safety of only a few hundred experimenters had to be considered; but now it is a problem of hundreds of thousands within the atomicenergy industry, and of the population at large. There are two main hazards to consider : those from electromagnetic and corpuscular radiations applied from without, and from radioactive materials taken into the organism.

Nuclear reactors must be enclosed within biological shields to absorb the $\gamma$-rays and neutrons. The re-processing of enfeebled reactor fuels and the extraction of plutonium and fission products must be carried out in a way which will minimize the escape of radioactive materials to the atmosphere or in drains. It is impossible, however, to prevent such escape completely and one must budget for a certain liberation of radioactive elements in routine operation, in addition to possible accidents. The question then is what is the radiation dose that can be tolerated.

All ionizing radiation is harmful to living tissue. Nevertheless, evolution has occurred in the presence of a natural background of radiation from cosmic and terrestrial sources, which produce a total dose of about 100 milli-roentgens per year. On the other hand, it is known that large doses have caused death and disease among scientific workers, luminous dial painters and miners in the Schneeberg; these effects can be reproduced by irradiating animals. In addition, radiation can induce unfavourable mutations. Little is known of the effects of radiation in human genetics and one has to infer from genetic investigations on the lower forms of life, where reproduction is rapid, such as the Drosophila or the mouse. The phenomenon of increased mutation-rates might be the limiting factor in the ultimate development of atomic power. What one can do at the moment, when still only a small fraction of the population is at risk, is to see that the national population dose of radiation released by man (the product of average dose of those occupationally exposed and the total number exposed) does not significantly exceed the national population dose from natural radiation. This is a form of com. promise adopted in establishing the maximum permissible dose, which usually is about one-tenth of the minimum damaging dose to man or experimental animal. Where this is unknown it is calculated from biological or physical data and extra safety factors are added.

One of the main problems is the disposal of fission products. Some can be concentrated to a small volume and made insoluble in water and stored underground or under water until they decay. A small fraction, however, will inevitably escape into the air or into drains, preferably direct to the sea, where the activity will be greatly diluted. If the energy equivalent to the present total coal consumption in Great Britain were obtained from fission, the total activity of, say, strontium-90 would amount to 